J. Clin. Chem. Clin. Biochem.

Vol. 25, 1987, pp. 245-251

(C) 1987 Walter de Gruyter \& Co. Berlin - New York

\title{
Determination of IgE Complexes and of Total IgE by Latex Immunoassay
}

\author{
By A. Bernard, J. P. Dieryckx, C. Viau
}

Medical and Industrial Toxicology Unit, Department of Occupational Medicine, Catholic University of Louvain, Brussels

\section{H. Bazin}

Experimental Immunology Unit, Department of Occupational Medicine, Catholic University of Louvain, Brussels, and

\section{R. Lauwerys}

Medical and Industrial Toxicology Unit, Department of Occupational Medicine, Catholic University of Louvain, Brussels

(Received February 3/December 15, 1986)

Summary: A sensitive immunoassay based on latex particle agglutination for the measurement of circulating IgE-containing complexes is described. In this method, the anti-IgE-coated particles are incubated with diluted serum and the resulting agglutination is quantified by turbidimetry or particle counting. In the latter version, the asșay is fully automated in a continuous flow system. IgE-containing complexes were detected in all tested sera. Increased concentrations were observed in about $80 \%$ of the subjects with elevated serum IgE. However, high levels of IgE-complexes may also be found in subjects with a normal or even a very low serum concentration of IgE.

The same latex immunoassay can be used for the determination of total IgE, after pepsin digestion of the $\gamma$-globulin fraction of the serum. The results obtained correlate well with those found with a sandwich radioimmunoassay $(\mathrm{r}=0.91, \mathrm{n}=83$ ). The present method, however, yields a greater number of significantly positive results than the radioimmunoassay, probably because of its ability to detect IgE entrapped in circulating complexes.

\section{Introduction}

The discovery of the IgE immunoglobulin class and its reaginic antibody activity has led to the development of a wide range of methods for the determination of total or specific IgE in serum. More recently, a new area of interest has emerged with the finding of high molecular weight forms of IgE in the sera of patients with the different allergic disorders $(1,2)$. Specific IgE complexes and symptoms of asthma were also produced by oral challenge with food allergens (3). In the early eighties, Williams et al. (4) found evidence of a naturally occurring IgM type of autoantibody directed against IgE. Raised levels of the autoantibody could be detected in sera from allergic patients but no clear correlation was found between the anti-IgE titre and the serum levels of IgE.

Inganäs et al. (5) found an IgG-type antibody directed against IgE in the sera of allergic individuals. These autoantibodies were partly blocked by endogenous IgE, indicating the presence of IgE-containing immune complexes in serum. 
The composition of these high molecular weight forms of IgE is probably variable. They may be aggregated $\operatorname{IgE}$, immune complexes of $\operatorname{IgE}$ with the allergen, immune complexes of $\operatorname{IgE}$ with anti-IgE antibodies, or immune complexes of the allergen with both IgG and IgE. The biological and pathological significance of these IgE-containing complexes is unclear. The few studies performed so far suggest that IgE complexes might play a pathogenic role in atopic $(6,7)$, rheumatic $(8,9)$ and infectious diseases $(10)$.

The study of the significance of these IgE complexes is partly limited by the availability of a rapid and simple technique for their determination. The ultracentrifugation and gel filtration methods used in the above-mentioned studies are time-consuming and unsuitable for screening a large number of samples. The possibility of measuring IgE immune complexes by a polyethylene glycol precipitation method has also been evaluated (11), but due to the low and variable precipitability of IgE complexes in polyethylene glycol, their exact quantitation by this method is probably impossible.

In this paper, we describe a simple and very sensitive assay for measuring circulating IgE-containing complexes. The same technique applied after pepsinic digestion of the $\gamma$-globulin fraction of the serum can also be used for the determination of total IgE. Using these two methods, we have studied the occurrence of IgE complexes and their relationships with total $\mathrm{IgE}$ in serum from both healthy subjects and patients with atopy.

\section{Materials and Methods}

Reagents

Polystyrene latex particles $(0.8 \mu \mathrm{m}$ in diameter $10 \%$ suspension, ESTAPOR K 109) were supplied by Dr J.C. Daniel, Rhône Poulenc Industries, Aubervilliers, France. The particles were used directly without washing.

Rabbit immunoglobulins against human IgE ( $\varepsilon$-chain specific) were obtained from Dakopatts Immunoglobulin, Copenhagen (lot 101B) and from Tago, Burlingame, CA 94101 (lot 040701). A pool of IgE-rich sera, calibrated by radioimmunoassay, was used as standard.

The glycine-buffered saline used throughout the assay was prepared by diluting 10 times a stock solution containing per liter, $1 \mathrm{~mol}$ of glycine, $1.7 \mathrm{~mol}$ of $\mathrm{NaCl}$ and $76 \mathrm{mmol}$ of $\mathrm{NaN}_{3}$ and adjusting the $\mathrm{pH}$ to 9 with $\mathrm{NaOH}$. The same stock solution but adjusted to $\mathrm{pH} 10.1$ was used for the stabilization of antibody-coated particles. Rheumatoïd factor activity was determined by the Behring (Marburg) latex agglutination test.

\section{Procedure}

\section{Adsorption of the antibody to the particles}

Sixty (for particle counting) or eighty (for turbidimetry) microliters of the anti-IgE DAKO antibody are diluted with $4 \mathrm{ml}$ of glycine-buffered saline, and $0.5 \mathrm{ml}$ of the $10 \%$ latex suspension is then added under continuous agitation. The mixture is incubated for $1 \mathrm{~h}$ at room temperature with slight agitation to maintain the particles in suspension (e.g. on a tube rotator). The particles are then centrifuged $(20000 \mathrm{~g}$ for $10 \mathrm{~min})$ and washed twice with $10 \mathrm{ml}$ of a $0.1 \mathrm{~mol} / 1 \mathrm{NaCl}$ solution containing $15 \mathrm{mmol} / 1 \mathrm{NaN}_{3}$. Resuspended in $10 \mathrm{ml}$ of this saline solution and stored at $4{ }^{\circ} \mathrm{C}$, this stock of antibody-coated particles can be used for at least 6 months.

\section{Preparation of the serum samples}

After the appropriate treatments described below, the sera are diluted in glycine-buffered saline containing $1 \mathrm{~g} / \mathrm{l}$ of bovine serum albumin (Sigma Chemical Co, St Louis, MI), adjusted to $\mathrm{pH} 9$ (particle counting) or 9.6 (turbidimetry).

\section{Determination of IgE-containing complexes}

For this assay, the sera are diluted at least 400 times. At this dilution, complement and chylomicrons do not interfere (12). IgE-containing complexes were assayed in 14 sera positive for rheumatoid factor (titre between 20 and 640). The highest IgE complex value (540 arbitrary units) was observed in a serum with a latex titre of 160 , while two sera with the highest latex titre (640) had IgE complex values just above the limit of normal (470 and 460 arbitrary units/l). The other sera had IgE complex values within normal limits. The interference of rheumatoid factor in the assay of IgE complexes therefore appears very unlikely.

\section{Determination of total IgE}

The concentration of total IgE is measured after pepsin digestion of the $\gamma$-globulin fraction of the serum prepared as follows (13): the serum is diluted twice at $0^{\circ} \mathrm{C}$ with a saturated solution of ammonium sulphate and centrifuged at $10000 \mathrm{~g}$ for $10 \mathrm{~min}$. The pellet is washed twice at $0^{\circ} \mathrm{C}$ with $1.75 \mathrm{~mol} / \mathrm{l}$ ammonium sulphate and finally dissolved in $0.2 \mathrm{~mol} / 1$ sodium acetate $\mathrm{pH}$ 4.5. The immunoglobulins are digested with pepsin (Sigma Chemical Co) at a final concentration of $0.5 \mathrm{~g} / \mathrm{l}$ for $24 \mathrm{~h}$ at $40^{\circ} \mathrm{C}$. To inactivate the enzyme, the $\mathrm{pH}$ is increased to 9 by adding 2 volumes of the glycine-buffered saline stock buffer pH 10.1 (see above) to 10 volumes of the solution.

\section{Stabilization of the latex particles'}

Just before the assay, latex particles from the stock preparation are resuspended and $0.5 \mathrm{ml}$ are pipetted into a solution containing $50 \mathrm{mg}$ of bovine serum albumin (Calbiochem, No. 126601, $\mathrm{pH} 7$ in distilled water) in $4 \mathrm{ml}$ of distilled water. The latter solution is freshly prepared in order to ensure a reproducible adsorption of bovine serum albumin to the latex. The latex suspension is then sonicated for $10 \mathrm{~min}$ (Branson Sonifier B12, Branson Sonic Power Co, Danburry, CT 06810) and its pH is increased to 10 by adding $0.5 \mathrm{ml}$ of the glycine-buffered saline stock buffer $\mathrm{pH} 10.1$.

\section{Assay}

Two methods, particle counting and turbidimetry, were used to quantify the agglutination of latex particles.

1. Particle counting

In this method, the agglutination is measured by counting the remaining unagglutinated particles as first proposed by Cambiaso et al. (14). The assay is performed automatically using a continuous flow system. The equipment, described in detail in 1.c. (12), consists of six modules:

a sampler which aspirates simultaneously the sample and latex particles,

a peristaltic pump,

a thermostatic bath,

a manifold (all from Cenco Instruments, Breda, The Netherlands), 
an optical cell counter (Technicon Instruments Tarrytown, NY 10591), and

a recorder.

The system has a throughput time of about $40 \mathrm{~min}$ and a sampling rate of $40 / \mathrm{h}$.

\section{Turbidimetry}

The agglutination of latex particles can also be quantified by measuring the decrease of absorbance of the latex suspension at $360 \mathrm{~nm}$ (15). The method is manual. Aliquots of sera (50 $\mu \mathrm{l})$ diluted in the glycine-buffered saline (containing $1 \mathrm{~g} / 1$ of bovine serum albumin) are pipetted into glass test tubes. Stabilized anti-IgE latex $(50 \mu \mathrm{l})$ is added to each tube and rapidly mixed, then the mixture is incubated at $40{ }^{\circ} \mathrm{C}$ for $60 \mathrm{~min}$ in a shaking water bath $\left(50 \mathrm{~min}^{-1}, 5.5 \mathrm{~cm}\right.$ amplitude). For the determination of total IgE, a serum blank is included containing $50 \mu \mathrm{l}$ of the sample and $50 \mu \mathrm{l}$ of the albumin solution (in glycine-buffered saline $\mathrm{pH} 10.1$ ) used to stabilize the latex. Incubation is stopped by adding $1 \mathrm{ml}$ of $0.27 \mathrm{~mol} / 1 \mathrm{NaCl}$ solution containing $1 \mathrm{ml}$ of Tween 20 per litre. The decrease in absorbance at $360 \mathrm{~nm}$ is measured with a Beckman spectrophotometer. Each tube is gently inverted $1-2$ times before transferring its content to the cuvette $(1 \mathrm{~cm}$ light path).

\section{Other methods}

The Phadebas IgE PRIST (Pharmacia Diagnostics AB, Uppsala, Sweden) was used for the determination of total IgE in serum. In the distribution studies, serum samples were chromatographed on a column $(100 \times 1.6 \mathrm{~cm})$ packed with Sephadex G-200 Fine (Pharmacia Fine Chemicals Uppsala, Sweden) and equilibrated with $50 \mathrm{mmol} / \mathrm{l}$ Tris- $\mathrm{HCl}$ buffer, $\mathrm{pH}$ 7.4, containing $0.2 \mathrm{~mol} / 1 \mathrm{NaCl}$ and $0.2 \mathrm{~g} / 1 \mathrm{NaN}_{3}$. One $\mathrm{ml}$ fractions were collected and the distribution of IgE was measured by the latex assay. Protein A was also obtained from Pharmacia Fine Chemicals.

\section{Results}

\section{Agglutination curves}

Figure 1 shows agglutination curves obtained by incubating anti-IgE-coated latex particles with increasing dilutions of a serum containing $1000 \mathrm{kIU} / 1 \mathrm{IgE}$ before and after digestion of the $\gamma$-globulin fraction by pepsin. As shown below, in untreated serum the particles are agglutinated by complexes containing IgE. When the $\mathrm{Fc}^{\prime \prime}$ fragment is released from these complexes, the agglutination is substantially reduced. Figure 1 also shows that the particle counting reading is more sensitive than turbidimetry by a factor of about 2 . The latter method however is sufficiently sensitive to measure IgE in normal sera.

\section{Specificity of the test}

\section{IgE complexes}

When sera are chromatographed on a Sephadex G200 column, the agglutination of anti-IgE-coated latex is always distributed in two peaks (fig. 2 a): a large peak eluting at the void volume followed by a smaller peak corresponding to IgE. When the percentages of agglutination are converted in concentrations units,

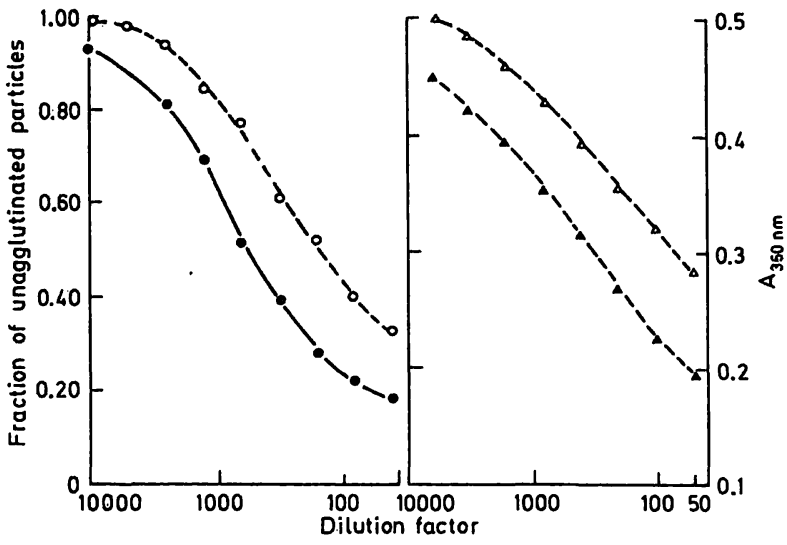

Fig. 1. Agglutination curves obtained by incubating anti-IgEcoated latex particles with serial dilutions of a serum containing $1000 \mathrm{kIU}$ IgE per litre before (closed symbols) and after (open symbols) peptic digestion of the $\gamma$-globulin fraction. Agglutination is quantified by counting the unagglutinated latex particles $(0,0)$ or by measuring the decrease of absorbance at $360 \mathrm{~nm}$ of the latex suspension $(\boldsymbol{\Delta}, \Delta)$.
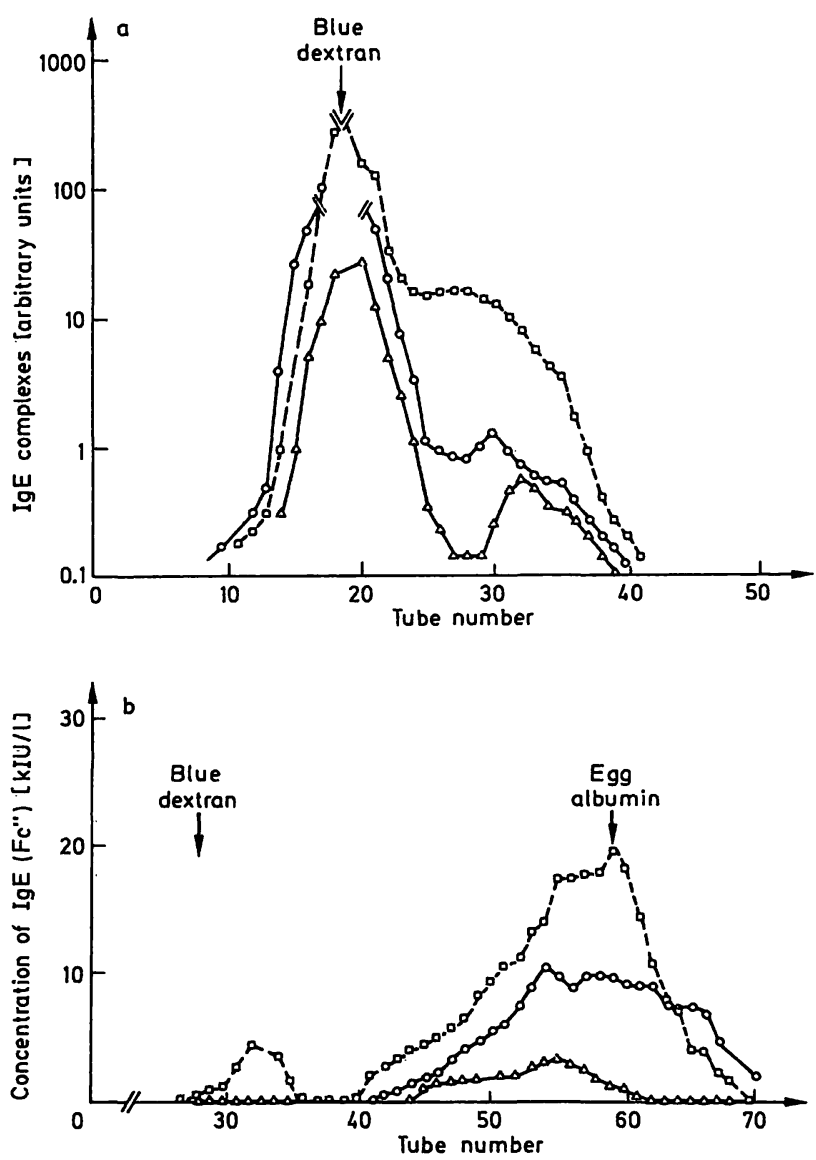

Fig. 2. Distribution of IgE assayed by latex immunoassay in the different fractions obtained by chromatography of three sera on Sephadex G-200 before (a) and after (b) peptic digestion of the $\gamma$-globulin fraction.

$\square-\square$ A.B.

O-O C.L.

$\Delta-\Delta$ J.P.D 
more than $90 \%$ of IgE detected by this agglutination test is present in high molecular weight complexes. We first questioned the specificity of the antibody but the latter has been checked by the peroxidase technique in tumour lymphoid tissue and by the ELISA method (personal communication from the supplier). No agglutination is observed when the antiIgE latex is incubated with purified IgM or IgG. Furthermore, the agglutination of anti-IgE-coated latex by these complexes is completely abolished by pretreating the serum with anti-IgE. These data confirm that the agglutination is really due to IgE entrapped in these complexes.

Several other tests were performed in order to better define the nature of these IgE-containing complexes. IgE complexes are partly heat labile. The agglutination is reduced by about $50 \%$ following heating at $56^{\circ} \mathrm{C}$ for $30 \mathrm{~min}$, which is in agreement with the known heat instability of IgE. IgE-containing complexes were not substantially precipitated by polyethylene glycol at a concentration of $4 \%$. This agrees with the observation of Djurup et al. (11) that from 0.2 to $20 \%$ of IgE complexes are precipitated under conditions where precipitation of monomeric IgE does not occur. The agglutination by these IgE complexes is not affected by the addition of heat-polymerized IgG. This treatment can thus be used to prevent a nonspecific agglutination of antibody-coated particles by the rheumatoild factor. We also treated serum samples containing various levels of IgE (as measured by PRIST) and IgE complexes with protein A (tab.

Tab. 1. Effect of protein A on IgE-containing complexes in serum

\begin{tabular}{lrll}
\hline $\begin{array}{l}\text { Serum } \\
\text { number }\end{array}$ & $\begin{array}{l}\left.\operatorname{IgA}^{\mathrm{a}}\right) \\
(\mathrm{kIU} / \mathrm{l})\end{array}$ & $\begin{array}{l}\text { IgE complexes } \\
\text { (arbitrary } \\
\text { units) }\end{array}$ & $\begin{array}{l}\text { Decrease }^{\mathrm{b}} \text { ) } \\
\text { by protein A } \\
(\%)\end{array}$ \\
\hline 1 & 1500 & 1000 & 0 \\
2 & 35 & 670 & 26 \\
3 & 25 & 250 & 48 \\
4 & 1420 & 750 & 35 \\
5 & 48 & 821 & 50 \\
6 & 42 & 1080 & 75 \\
7 & 50 & 160 & 12 \\
8 & 35 & 2400 & 93 \\
9 & 1540 & 970 & 52 \\
10 & 900 & 850 & 53 \\
11 & 520 & 500 & 46 \\
12 & 1200 & 1670 & 56 \\
13 & 160 & 1210 & 49 \\
\hline
\end{tabular}

a) Measured by PRIST

b) Sera incubated overnight at $4{ }^{\circ} \mathrm{C}$ with $100 \mathrm{mg} / 1$ protein $\mathrm{A}$, then centrifuged at $2000 \mathrm{~g}$ for $10 \mathrm{~min}$.
1). In some sera (e.g. Nos. 1, 2, 7), this treatment has little or no effect on the amount of IgE complexes. The latter probably consist of immune complexes between an allergen and IgE. By contrast, in 2 other sera (Nos. 6 and 8), the level of IgE complexes is drastically reduced by the pretreatment with protein A. It is very likely that these complexes are mainly formed from IgE and IgG anti-IgE antibodies and that they contain no allergen. This explanation would be consistent with the fact that the IgE level of both sera as measured by PRIST was normal. But it is also possible that these protein A-binding IgE complexes are immune complexes between both IgG and IgE antibodies and that the antigen stimulated their production. In that case, the simultaneous presence of high levels of IgG relative to IgE would prevent the antigen from behaving as a true allergen. Finally, we also compared the anti-IgE antibody from Dako with that from Tago for the determination of IgE complexes in 15 sera. The results obtained using these two antibodies were highly correlated $(r=0.97)$.

\section{Total IgE}

When the $\gamma$-globulin fraction of the serum is digested by pepsin and separated on Sephadex G-200, the void volume agglutination peak and the IgE peak disappear almost completely (fig. 2 b). A broad agglutination peak is observed corresponding to the $\mathrm{Fc}^{\prime \prime}$ fragment of IgE. Thus, under these conditions, the method measures the total amount of IgE present in the serum, i.e. both monomeric IgE and $\operatorname{IgE}$ entrapped in immune complexes.

\section{Analytical variables}

When purified IgE (final concentration of $7 \mathrm{mg} / \mathrm{l}$ ) was added to 10 different sera with low and high levels of IgE complexes, the recovery (tested $24 \mathrm{~h}$ later without no pepsin digestion) was $99.2 \%$ (SD: $16.7 \%)$. For the assay of total IgE (pepsin digestion), 10 sera containing 89 to $350 \mathrm{kIU} / 1$ were mixed with an aliquot of an IgE-rich serum to increase their concentrations by $170 \mathrm{kIU} / \mathrm{l}$. The mean recovery was $108.4 \%$ (SD: 13.9\%). The within-run precision for the determination of IgE complexes or of total IgE was that of the automated system described previously, i. e. 5 to $10 \%$. The CV obtained by analysing IgE complexes in a serum pool 25 times over 6 months was $13.4 \%$. Total $\mathrm{IgE}$ was measured 4 times over 2 weeks in 5 sera containing from 50 to 1000 $\mathrm{kIU} / \mathrm{l}$ and the mean $\mathrm{CV}$ was $12.5 \%$. 


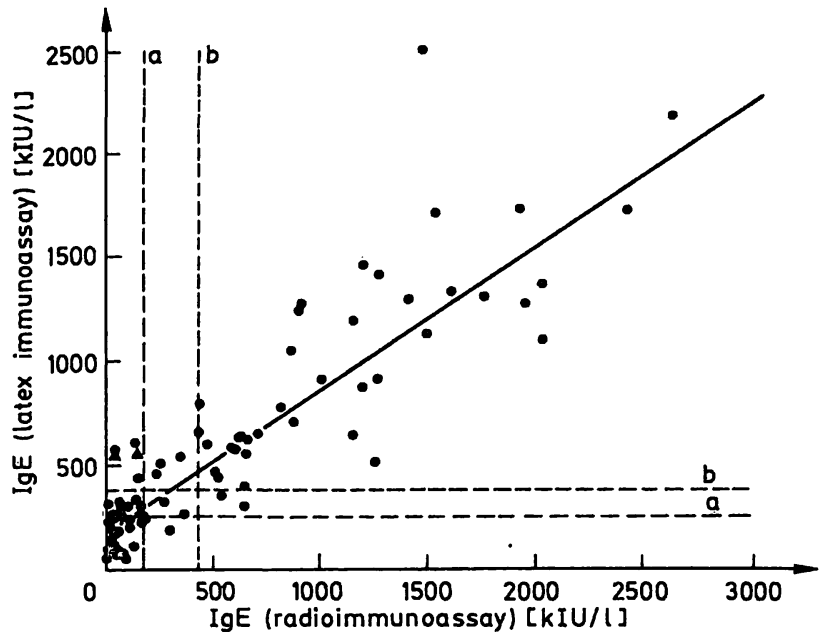

Fig. 3. Correlation between latex immunoassay and radioimmunoassay (PRIST) for the determination of IgE in 83 sera. The dashed lines represent the 95th percentile (a) or the geometric mean +2 geometric SD (b) of the values found in a group of 36 healthy subjects. $\mathrm{y}=189+0.77 \mathrm{x} ; \mathrm{r}=0.91$

Relationship between IgE (RIA) and total IgE measured by latex immunoassay

Figure 3 shows the correlation between RIA (PRIST) and latex immunoassay (pepsin digestion) for the assay of $\operatorname{IgE}$ in 83 serum samples. The latex technique yields a higher number of positive results than RIA. For instance, if the geometric mean +2 geometric $\mathrm{SD}$ is used as cut off value, 8 sera are found to be positive by latex immunoassay against only 2 by RIA. In the case of the two samples represented by a triangle, the presence of high levels of IgE ( $\mathrm{Fc}^{\prime \prime}$ fragment) was confirmed by chromatography on Sepha$\operatorname{dex} G=200$. The profile obtained with one of these two samples (C. L.) is shown in figure 2. It is also interesting to note that in apparently healthy subjects, the values of $\mathrm{IgE}$ determined by latex immunoassay are frequently 2 to 3 times higher than those obtained by RIA. In contrast to RIA, we never observed IgE concentrations below $50 \mathrm{kIU} / 1$ in the latex immunoassay. A possible explanation for this discrepancy is the fact that the sandwich technique used in the Phadebas IgE PRIST cannot detect IgE entrapped in circulating immune complexes and thus underestimate the total IgE concentration in serum.

Relationship between IgE (RIA or latex immunoassay after pepsin digestion) and IgE complexes in serum

The concentrations of IgE complexes and of IgE (assayed by PRIST) were measured in 106 sera from

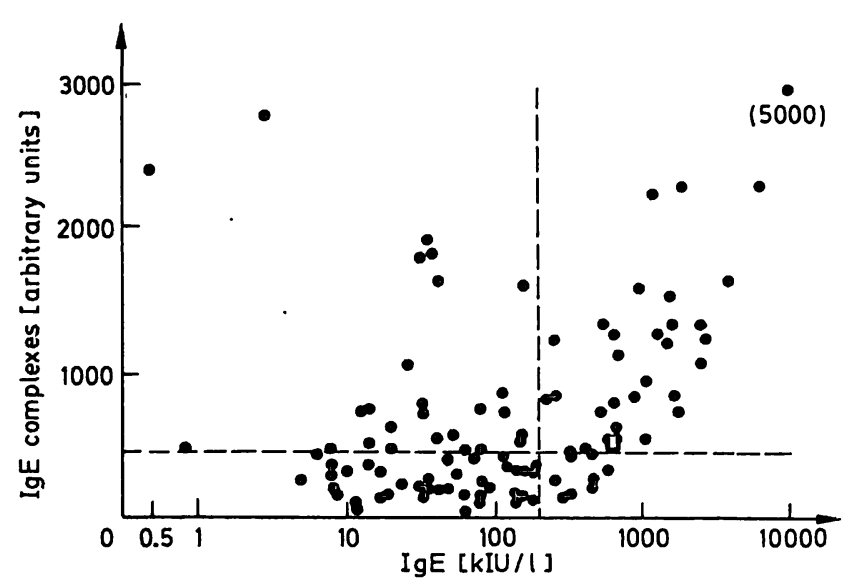

Fig. 4. Relationship between IgE-containing complexes (assayed by latex immunoassay) and serum IgE (assayed by PRIST), $n=106$. The dashed lines represent the 95th percentile of the values found in a group of 36 healthy subjects.

non atopic subjects or from patients with signs of allergy. As shown in figure 4, high levels of circulating IgE complexes are found in sera with high, normal or even very low IgE (PRIST) concentrations. In subjects with increased serum $\operatorname{IgE}(>200 \mathrm{kIU} / \mathrm{l}$ ), the concentrations of IgE complexes are in most cases $(83 \%)$ elevated and on the average correlated with that of serum IgE. Similar observations were made when comparing IgE complexes and the IgE concentration in serum as determined by latex immunoassay after pepsin digestion (results not shown).

\section{Discussion}

The method described in this paper for measuring IgE-containing complexes relies on the agglutination by these complexes of calibrated particles coated with an anti-IgE antibody, specific for the $\varepsilon$-chain. The reason why monomeric IgE is hardly detected in this assay (fig. 2 a) lies in its poor agglutinating capacity compared with that of IgE complexes. Immunoglobulin molecules have a $\mathrm{Y}$ shaped structure with hingelike flexible arms. As shown with IgG (15) conformational transitions are induced by change in $\mathrm{pH}$. When the molecule is fully charged, either cationically (at low $\mathrm{pH}$ ) or anionically (at high $\mathrm{pH}$ ), the arms are completely extended because of charge repulsion. However, at a $\mathrm{pH}$ around 7.8 (no net charge), there is minimal intramolecular charge interaction and the arms collapse owing to intramolecular attractive hydrophobic interactions. To get an agglutination with 
monomeric IgE, it is necessary that at least two anti-IgE antibody molecules adsorbed to different particles can interact with the same $\mathrm{Fc}$ fragment of an IgE molecule. Considering that at the $\mathrm{pH}$ of the assay (around 9.8), IgE molecules have a very wideopened structure, this crosslinking is restricted by steric hindrance. By contrast in IgE-containing complexes (e.g. IgE-allergen complexes), several Fc fragments may be exposed at the outer surface of the complexes and are readily accessible to the antibodies. Under these conditions, latex particles can be agglutinated through the interaction of anti-IgE antibodies with different $\mathrm{FC}$ fragments without steric hindrance. For this reason, IgE-containing complexes have a much higher agglutinating activity than monomeric IgE and even if they are present in serum in much lower ponderal concentrations, they contribite to the major part of the agglutination.

To determine the concentration of total IgE in serum by latex immunoassay, proteolysis of IgE-containing complexes is required. Magnusson et al. (16), however, have described an automated latex immunoassay called particle counting immunoassay (PACIA) for serum IgE, based on the agglutimation of anti-IgEcoated latex particles. Although relying on the same principle as the assay describing in this paper, the PACIA method measures directly the concentration of total IgE in serum without any interference from IgE-containing complexes. This difference cannot be ascribed to the use of $F\left(a b^{\prime}\right)_{2}$ fragments of anti-IgE on the latex particles in the PACIA method. We also prepared $F\left(a b^{\prime}\right)_{2}$-coated latex particles but no difference was observed in their agglutinability by IgE complexes. A likely explanation for this discrepancy between the two assays is that the various additives used in combination in the PACIA method (i.e. $\mathrm{NaCl}$ at half saturation and $6 \%$ PEG) might eliminate the IgE complexes and also decrease the electrostatic repulsions of the IgE arms. The pepsin treatment is

\section{References}

1. Brostoff, J., Johns, P. \& Stanworth, D. (1977) Lancet II, $741-742$

2. Orste, U., Calligaris, V. \& Ruffili, A. (1983) Int. Arch. Allergy. Appl. Immun. 71, 267-270.

3. Brostoff, J., Carini, C., Wraith, D. G. \& Johns, P. (1979) Lancet $I, 1269-1270$.

4. Williams, R. C., Griffiths, R. W., Emmons, J. D. \& Fiels, R.C. (1981) J. Clin. Invest. $65,51-61$.

5. Inganas, M., Johnsson, S. \& Bennich, H. (1981) Int. Arch. Allergy Appl. Immun. 65, 51-61.

6. Anderson, C. I. \& Spiegelberg, H. L. (1981) J. Immunol. $126,2470-2474$ time consuming but it offers the advantage of an accurate estimation of the total IgE present in serum, which includes free $\operatorname{IgE}$ and $\operatorname{IgE}$ entrapped in immune complexes. This is probably the reason why the $\operatorname{IgE}$ values obtained after this treatment are higher than those observed with the PRIST method particularly in the low concentration range.' The pepsin digestion also successfully eliminates the rheumatoid factor and the complement which are common sources of interference in latex agglutination techniques.

The biological significance of IgE complexes and hence the relevance of their determination is unclear. They are present in small amounts in sera from all the apparently healthy subjects we have tested so far. High levels are frequently associated with elevated concentrations of total IgE. But they may also be found in sera from asymptomatic subjects with low levels of IgE.

The experiment with protein $\mathrm{A}$ indicates that the composition of IgE complexes is variable. It is very likely that the IgE complexes found in the sera from atopic patients contain specific IgE and the allergen. However, IgG or IgM antibodies directed against the allergen or IgE itself (autoantibodies) may also be present.

Furthermore, as complement can be activated by IgE (18) or by immunoglobulins of other classes involved in the complexes, complement components may also be part of the IgE-containing complexes.

\section{Acknowledgement}

We are very thankful to Dr J. C. Daniel (Rhộne-Poulenc) for providing us with batches of polystyrene latex particles (ESTAPOR K109). Mr X. Dumont is gratefully acknowledged for his technical assistance. C. Viau is Research Fellow of Institut de Recherches en Santé et en Sécurité du Travail du Québec, Montréal, Canada. A. Bernard is a Chercheur Qualifié du Fonds National Belge de la Recherche Scientifique.
7. Melewicz, F. M., Zieger, R. S., Mellon, M. H., O'Connor, R. D. \& Spiegelberg, H. L. (1981). J. Immunol. 126, 1592-1599.

8. Meretey, K., Falus, A., Erhardt, C. G. \& Maini, R.N. (1982) Ann. Rheum. Dis. 41, 405-408.

9. Zuraw, B. L., O'Hair, C. H., Vaughan, J. H., Mathison, D. A., Curd, J. C. \& Katz, D. (1981) J. Clin. Invest. 68, 1610-1613.

10. Stevens, W. J., Feldmeir, H., Bridts, G. \& Dalfalla, A. A. (1982) Clin. Exp. Immunol. 52, 144-152.

11. Djurup, R., Kappelgaard, E., Stahi Skov, P., Permin, H. \& Nielsen, H. (1984) Allergy 39, 395-406. 
12. Bernard, A. \& Lauwerys, R. (1983) Clin. Chem. 29, 1007-1011.

13. Mayer, R. J. \& Walker, J. H. (1980) Immunochemical methods in the biological sciences: enzymes and proteins. Academic Press, New York - London, p. 132.

14. Cambiaso, C. L., Leek, A. E., De Steenwinkel, F., Billen, J. \& Masson, P. L. (1977) J. Immunol. Methods 18, 33-44.

15. Bernard, A. \& Lauwerys, R. (1982) Clin. Chim. Acta 119, $335-339$.
16. Bagchi, P. \& Birnbaum, S. M. (1982) J. Coll. Int. Sci. 83 , $460-475$.

17. Magnusson, C. G. M., Collet-Cassart, D., Merrett, T. G. \& Masson, P. L. (1981) Clinical Allergy 1, 455-461.

18. Saint-Remy, J. M. R., Magnusson, C. G. M. \& Masson, P. L. (1983) J. Immunol. 130, $1341-1344$.
A. Bernard
Industrial Toxicology
and Occupational Medicine Unit
Catholic University of Louvain
30.54 Clos Chapelle-aux-Champs
B-1200 Brussels 
